Munteán, László. "Legát, Tibor and Dávid Sándor (eds). 2018. Elfelejtett Budapest / Forgotten Budapest. Trans. Virág Tyekvicska. Budapest: Fortepan-könyvek / ZuckerMüvek Kft. 105 pp. Illus.” Hungarian Cultural Studies. eJournal of the American Hungarian Educators Association, Volume 12 (2019) DOI: 10.5195/ahea.2019.372

\title{
Legát, Tibor and Dávid Sándor (eds). 2018. Elfelejtett Budapest / Forgotten Budapest. Trans. Virág Tyekvicska. Budapest: Fortepan- könyvek / ZuckerMúvek Kft. 105 pp. Illus.
}

\author{
Reviewed by László Munteán ${ }^{1}$, Radboud University Nijmegen, the Netherlands
}

The bilingual volume Elfelejtett Budapest / Forgotten Budapest offers a rich selection of amateur photographs depicting a variety of locations in Budapest that during the twentieth century have undergone radical transformation or have even completely disappeared. This volume is the first of a planned ten-volume series, each of which will feature a hundred photographs selected from the Fortepan Hungarian online amateur photo archive (www.fortepan.hu).

When two friends, Miklós Tamási and Ákos Szepessy, launched Fortepan in 2010, it contained only a handful of family photographs salvaged from flea markets and house clearances. Today, the archive contains more than a hundred thousand photographs taken between 1900 and 1990, mostly donated by individuals and institutions. With Szepessy no longer involved in the project Tamási continues to tackle the enormous work of selecting and digitizing photographs. He has quit his job as head of Galeria Centralis, a branch of the Open Society Archives at Central European University, to fully dedicate himself to Fortepan. The original idea behind this exponentially growing online archive was to shed light on mundane details of everyday life that are often omitted from the visual canon of twentieth century Hungarian history. Licensed under Creative Commons, the archive allows visitors to freely download and use its content with only the obligation to indicate Fortepan as the source. Registered visitors can also add to the images tags, which in turn facilitate searches in the archive. Over the past nine years, Fortepan has become a prominent research tool for students and scholars of a variety of disciplines and, not the least, a means to engage in nostalgia.

Once digitized and uploaded into the Internet archive, analogue photographs are given a new life. They are no longer merely circulated in albums passed around family members, friends, and guests but viewed by visitors of the Fortepan website who stumble upon them by chance as they launch their keyword search. The stories and memories that these images would evoke in a family setting are absent from the domain of the Internet, and instead, visitors perceive them as impersonal traces of bygone eras, or as documents of fashion, style, design, architecture and the fleeting moments of everyday life. Fortepan is thus a crucible of transformations that play out on three different levels: first, analogue photographs are turned into digital form; second, they are taken from the private into the public realm; and third, from vehicles of individual or family

\footnotetext{
${ }^{1}$ l.muntean@let.ru.nl
}

(cc) EY

ULLS D-Serke 
Munteán, László. "Legát, Tibor and Dávid Sándor (eds). 2018. Elfelejtett Budapest / Forgotten Budapest. Trans. Virág Tyekvicska. Budapest: Fortepan-könyvek / ZuckerMüvek Kft. 105 pp. Illus.” Hungarian Cultural Studies. eJournal of the American Hungarian Educators Association, Volume 12 (2019) DOI: 10.5195/ahea.2019.372

memories they become part of a collective photographic heritage. Ironically, with the publication of Elfelejtett Budapest / Forgotten Budapest, the digitized images are once again turned into printed material, albeit in a completely new context. The book's introduction and the texts that accompany the photographs have been written by Tibor Legát who, along with Dávid Sándor, selected the photographs for this volume. A man of many talents, Legát established his name long ago as an alternative musician, journalist, and author whose book Közlekedik a fóváros ['Public Transportation in Budapest'] was a bestseller when it appeared ten years ago. A revised edition of this book was republished in 2018 (Budapest: Scolar Kft.).

If there is no memory without forgetting, Elfelejtett Budapest / Forgotten Budapest is predicated on what has vanished from our collective memory of the city. The book comprises a plethora of images taken at various sites, mainly on the Pest side, that are often difficult to recognize, even for someone born and raised in the city. Many of the locations in the photographs have either completely changed or the buildings in them had only been built for temporary purposes, such as the bridge between Batthyány tér and Kossuth tér, the only functioning bridge across the Danube in the wake of World War II (90-91). Even less well known is a bridge that in the early 1960s was removed from the Zagyva River, in North-Eastern Hungary, and installed at Astoria Square in Budapest to ensure tram traffic during the construction of the subway in that area (21). Other photographs depict buildings that were destroyed during World War II, such as the so-called Elevator House, once considered to be a technological feat for its complex mechanism of storing crops (38-39), while other buildings have fallen victim to the wrecking ball of modernization, such as the old National Theater at Blaha Lujza tér (46-47). To many people some of these locations may be unrecognizable, while for others they bring back memories of childhood. Having grown up in the Újlipótváros of the 1980s, in my own case, I was pleasantly surprised to find a photograph of the old playground at Jászai Mari tér, with its trademark concrete and iron installations that have, for better or worse, long ago disappeared (81).

Here, it is fitting to mention another volume from 2018, A magyar zsidó építőmüvészek öröksége: Lajtán innen és Lajtán túl ['Hungarian Jewish Architects'], by Tibor Gottdank (Budapest: K.u.K.). If the photographs in Elfelejtett Budapest / Forgotten Budapest confront readers with such forgotten or half-remembered layers of the city's past, Gottdank's book offers a meticulously researched and assembled encyclopedia of Hungarian-Jewish architects who had been instrumental to the rise of Budapest as a late nineteenth-century metropolis but whose fame and lives came to an untimely end with the Jewish laws and the subsequent deportations in World War II. Although architects such as Béla Lajta, Lajos Kozma, and Marcel Brauer are wellknown both nationally and internationally, little is known of their Jewish roots, their contributions to Hungarian Art Nouveau, Art Deco, and the Bauhaus, not to mention the dozens of lesser known architects who were denied contracts, forced to emigration or were killed. For instance, the Löffler brothers, who designed such prominent buildings as the Orthodox Synagogue in Budapest's seventh district, each fell victim to persecution. Béla Löffler is assumed to have emigrated to Palestine, where he died around 1935, while Sándor was killed in unknown circumstances and his name appears on a list of Holocaust victims on a memorial plaque in Sopron, Western Hungary (199). Gottdank's book is a timely tribute to architects who have played a key role in shaping the cityscape and whose lives and careers were cut short on grounds of their ethnicity and religion. It is also an invaluable source-material for researchers and anyone interested in Hungarian architectural history. 
Munteán, László. "Legát, Tibor and Dávid Sándor (eds). 2018. Elfelejtett Budapest / Forgotten Budapest. Trans. Virág Tyekvicska. Budapest: Fortepan-könyvek / ZuckerMüvek Kft. 105 pp. Illus.” Hungarian Cultural Studies. eJournal of the American Hungarian Educators Association, Volume 12 (2019) DOI: 10.5195/ahea.2019.372

Whereas Gottdank's text is a joy to read despite its encyclopedic structure, Legát's texts that accompany the excellent selection of images in Elfelejtett Budapest / Forgotten Budapest are less successful. Already in the preface, the reader is given a taste of Legát's nostalgia for the period of Budapest's rise into a metropolis in the second half of the nineteenth century under the auspices of the Public Works Council that supervised major developments and constructions. What follows this period of prosperity, Legát contends, is a "downward curve" of modernization: "It may sound terrible, but it is true: for the city of Budapest, the twentieth century was an era of wartime and revolutionary tragedies and a series of unrefined, unfinished urban arrangements" (10). Certainly, history has taken its toll on the city's characteristic nineteenth century building stock but dismissing post-World War II modernization as nothing but detrimental is unnecessarily reductive. Think, for instance, of such late modernist projects as István Nyíri’s long-distance bus station at Erzsébet tér or the extension of Terminal 1 at Ferihegy Airport by Károly Dávid Jr. and Márton Szabó. Both of these buildings were built in the late 1940s, bringing the legacy of the Bauhaus to the post-World War II era. Building R of the Budapest Technical University, designed by Gyula Rimanóczy and János Kleinsel between 1951-1955, is among the best achievements of Social Realism, which still serves its original function.

Certainly, many projects conceived in the period between 1960 and 1990, such as the hotels along the Pest side of the Danube and in the Buda Castle, did more harm than good for the city. However, more recent developments, such as József Finta's Westend City Center, replaced a disheveled area along the tracks leading out of the Western Railway Station with a mixed-use mall-complex, which does meet its purpose, even if it is not particularly pleasing aesthetically. Values and tastes change over time and the rose-tinted glasses of nostalgia for the distant past unduly put the blame on the recent past.

Unfortunately, Legát's bitterly nostalgic tone prevails throughout the volume, which begs the question as to who the target audience of the book actually is. Given the numerous references and implications to old street-names, stories, and use of urban slang it would be logical to assume that the book is intended for local audiences or people familiar with Budapest and its history. However, the English translations of the texts indicate that the editors also had an international readership in mind. While such an ambition is laudable, the English texts are mainly nothing more than literal translations of Legát's poetic sentences, which makes little sense for someone who is not an inhabitant of the city. Although the book's translator, Virág Tyekvicska, did her best to edit out unnecessarily confusing references and Hungarian slang, it would have been helpful to provide more historical context for non-Hungarian readers. In addition, the translation would also have benefitted from a more thorough revision, as presently a large number of stylistic and grammatical imperfections remain, not to mention a factual mistake, resulting from the translator's attempt to contextualize the term kitörési kísérlet ['outbreak attempt'] in the Széna tér area: "Even today it [Széna tér] lacks significance, no wonder it only comes up in connection the [sic] 1944 outbreak attempt against the Germans and the Revolution of 1956 against the Russians" (85). In reality, the outbreak was attempted by German and Hungarian troops across the Russian blockade, and the Revolution of 1956 was fought against Communist rule and put down by the Red Army.

Although glitches in the translation and the lack of historical context in the English texts are detrimental to the overall quality of the book, the true asset of Elfelejtett Budapest / Forgotten Budapest is that its excellent selection of photographs from Fortepan not only sheds light on forgotten layers of the city but it does so through amateur photographs. As such, the 
Munteán, László. "Legát, Tibor and Dávid Sándor (eds). 2018. Elfelejtett Budapest / Forgotten Budapest. Trans. Virág Tyekvicska. Budapest: Fortepan-könyvek / ZuckerMüvek Kft. 105 pp. Illus.” Hungarian Cultural Studies. eJournal of the American Hungarian Educators Association, Volume 12 (2019) DOI: 10.5195/ahea.2019.372

book, alongside the upcoming volumes in the series, continues the work of Fortepan insofar as it contributes to the dissemination of amateur photography as an integral part of Hungarian photographic memory and heritage. 